\title{
RECOVERY OF BLASTOCYSTS AND INDUCTION OF IMPLANTATION FOLLOWING ARTIFICIAL INSEMINATION OF IMMATURE MICE
}

\author{
PHILIP J. DZIUK AND MEREDITH N. RUNNER \\ University of Illinois, Urbana, Illinois, U.S.A. and \\ Roscoe B. Jackson Memorial Laboratory, Bar Harbor, Maine, U.S.A.
}

(Received 8th February 1960)

\begin{abstract}
Summary. Prepuberal female mice were hormonally induced to ovulate and were artificially inseminated with spermatozoa that had been stored in vitro from 2 to $24 \mathrm{hr}$. No difference was found in fertilizing ability due to storing spermatozoa for different periods of time. Inseminations were performed at various times relative to ovulation, ranging from $2 \mathrm{hr}$ before ovulation to $\mathrm{I} 3 \mathrm{hr}$ after ovulation. The time of insemination relative to ovulation did influence the percentage of ova that were blastocysts and it appeared that the optimum time for insemination is about $6 \mathrm{hr}$ after ovulation. Blastocysts were recovered from females following insemination up to $\mathrm{I} 3 \mathrm{hr}$ after ovulation. Blastocysts were capable of implantation and developing to 18 -day foetuses under the stimulus of progesterone administered orally to the mice. Blastocysts produced by artificial insemination of prepuberal mice are capable of implantation and development after a delay in implantation of at least I I days. Further refinements of the techniques described may permit more detailed study of the viability of germ cells produced and handled under a wide variety of conditions.
\end{abstract}

\section{INTRODUCTION}

The determination of the fertile life of mouse eggs (Braden \& Austin, I954 a, b) has not been attempted with the aid of artificial insemination as has been the case in rats (Blandau \& Jordan, I941 ; Blandau, I952) and some other species. The technique of artificial insemination in mice has been used for other purposes by several workers (Snell, Hummel \& Abelmann, I943, I944; Runner, 1947; Kile, I951; Edwards, I 955) with varying degrees of success. Most reports have indicated only a $15^{-}$to $20-\mathrm{min}$ in-vitro storage period for the spermatozoa prior to insemination. Part $\mathrm{I}$ of this paper reports results of attempts to store spermatozoa in vitro up to $24 \mathrm{hr}$ and to determine the postovulatory fertilizable life of mouse eggs with the aid of various artificialinsemination procedures.

Smithberg \& Runner (1956), using prepuberal mice induced to ovulate and mate by gonadotrophins, also induced implantation and foetal development 
by daily injections of progesterone. Smithberg (1958) later induced implantation in prepuberal mice by other progestationally-active compounds.

Part 2 reports the results of tests to determine whether ova produced in immature females and fertilized by artificially inseminated spermatozoa could implant and develop.

In addition to artificially inseminating the immature females, rather than mating naturally, the exogenous hormones (e.g. progesterone) necessary for implantation in immature mice were administered orally in the diet. This was attempted to avoid the tedium and inconvenience of daily injections and to avoid stress to the females associated with daily handling at injection.

\section{MATERIALS AND METHODS}

PART I

Prepuberal, hybrid (DBA/2J $\left.\times \mathrm{C}_{57} \mathrm{BL} / 6 \mathrm{~J}\right)$, female mice approximately 3 to 4 weeks old (Io to $15 \mathrm{~g}$ ) were induced to ovulate by a slight modification of the procedure described by Runner \& Gates (1954). In most cases, the females were injected with 2 i.u. of pregnant-mare serum gonadotrophin (PMS) and 38 to $5^{\mathrm{I}}$ hr later given 2 units of human chorionic gonadotrophin (HCG). Both hormones were given by intraperitoneal injections in $0.4 \mathrm{ml}$ of $0.9 \%$ sodium-chloride solution. Ovulation for a group of animals has been shown to be half complete by approximately $12 \mathrm{hr}$ after injection of HCG (Runner \& Palm, I953; Gates \& Beatty, 1954); therefore, for purposes of this report ovulation time was considered to be I $2 \mathrm{hr}$ after HCG injection.

The spermatozoa for insemination were obtained from males of Strain 129 at least I year old which were killed by breaking their necks. Dead males were exposed to room temperature for $\frac{1}{2}$ to $2 \frac{1}{2} \mathrm{hr}$ before dissection, to prevent cooling of spermatozoa at an excessive rate (temperature shock). The spermatozoa were removed from either or both the vas deferens and the epididymis. They were suspended in a $9.5 \%$ solution of reconstituted, dry-skim milk which was heated in a boiling water-bath for at least Io min, and then cooled to room temperature before the spermatozoa were added (Melrose, 1956). The interval of time from collection of spermatozoa to insemination ranged from $\frac{1}{2}$ to $24 \mathrm{hr}$. When spermatozoa were stored for more than $2 \mathrm{hr}$, the suspension was slowly cooled to, and held at, $7^{\circ} \mathrm{C}$. Cooling was accomplished by placing the tube containing the suspended spermatozoa in a larger flask containing at least $300 \mathrm{ml}$ of water (room temperature) before refrigeration. Sperm suspensions were at, or slightly below, room temperature when inseminated.

Artificial insemination was accomplished by depositing spermatozoa in the uterus by way of the cervix (Text-fig. I). A glass speculum held by a ring stand and illuminated by a microscope lamp served to aid in visualizing the external os of the cervix. A square-tipped, blunted, 22-gauge needle, with a $90^{\circ}$-angle bend at such a point that the base of the speculum prevented insertion of the needle more than $\frac{1}{8}$ " beyond the vaginal end of the speculum, was used to deposit the spermatozoa in the uterus. This arrangement insured a uniform deposition site for the spermatozoa and prevented puncture of the uterine wall during insemination. No attempt was made to insert the needle 
into both horns because pilot trials with a dye suspension indicated the injecta became distributed into both uterine horns even though the needle extended a short distance into only one horn. Blastocysts and foetuses were routinely recovered from both right and left uterine horns following insemination.

At the time of insemination, females were not anaesthetized but were restrained by grasping the skin at the back of the neck and the tail with the left hand. The mouse was then held on the speculum (Text-fig. I) while the syringe and needle were manipulated with the right hand. One person performing all operations could inseminate at least one mouse per minute.

The volume of sperm suspension inseminated per female varied from $0.035 \mathrm{ml}$ to $0.12 \mathrm{ml}$. Difficulty was encountered in accurately inseminating volumes less than $0.05 \mathrm{ml}$ and if the volume inseminated was in excess of $0 . \mathrm{r} \mathrm{ml}$,

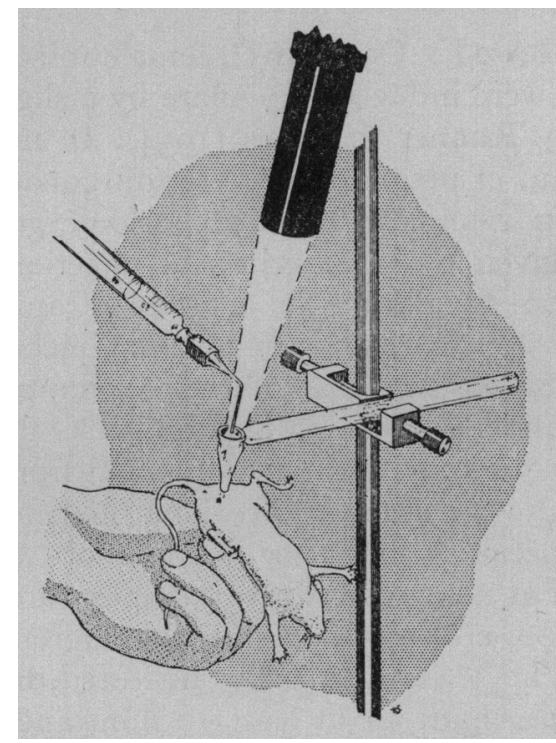

TeXT-FIG. 1. Insemination equipment and technique.

part of the suspension was often forced out of the cervix at insemination. This tended to limit the range of volume that could be inseminated.

After pilot trials showed that motility of mouse spermatozoa could be maintained for $72 \mathrm{hr}$ or more in heated reconstituted dry-skim milk, no further attempt was made to improve the suspension medium. Improvement in maintenance of motility and fertilizability could probably be realized by further experimentation with handling techniques, media and additives. Spermatozoa from a single male were suspended in a volume adequate for inseminating four to eight females. Spermatozoa were not counted in Part I and no specific effort was made to determine optimum numbers to be used for each insemination. Motility estimates were made at the time of insemination based on a scale of o (immotile) to 5 (very motile). Insemination time ranged from $2 \mathrm{hr}$ before ovulation to $\mathrm{I} 3 \mathrm{hr}$ after ovulation. 
TREATMENTS AND RESULTS OF INDUGTION OF IMPLANTATION

\begin{tabular}{|c|c|c|c|c|c|}
\hline $\begin{array}{c}\text { No. mice } \\
\text { inseminated }\end{array}$ & $\begin{array}{l}\text { Age of mice at } \\
\text { ovulation } \\
\text { (days) }\end{array}$ & $\begin{array}{l}\text { Ovulation-to- } \\
\text { insemination } \\
\text { interval } \\
\quad(h r)\end{array}$ & $\begin{array}{c}\text { No. } \\
\text { spermatozoa } \\
\text { per } q \times 10^{6}\end{array}$ & $\begin{array}{l}\text { Insemination to } \\
\text { implantation } \\
\text { induction } \\
\text { (days })\end{array}$ & $\begin{array}{l}\text { Treatment } \\
\text { for implant } \\
\text { induction }{ }^{\mathrm{c}}\end{array}$ \\
\hline $\begin{array}{l}5 \\
5 \\
6 \\
6\end{array}$ & $\begin{array}{l}40 \\
40 \\
80 \\
80\end{array}$ & $\begin{array}{l}-1 \\
=1 \\
=1 \\
-1\end{array}$ & $\begin{array}{l}6^{\mathrm{a}} \\
6^{\mathrm{a}} \\
6^{\mathrm{a}} \\
6^{\mathrm{a}}\end{array}$ & $\begin{array}{l}\text { I } \\
\text { I } \\
\text { I }\end{array}$ & $\begin{array}{l}\text { Prod +oil } \\
\text { None } \\
\text { Prod +oil } \\
\text { None }\end{array}$ \\
\hline $\begin{array}{l}5 \\
5 \\
5 \\
5\end{array}$ & $\begin{array}{l}40 \\
40 \\
45 \\
45\end{array}$ & $\begin{array}{l}+12 \\
+12 \\
-2 \\
-2\end{array}$ & $\begin{array}{l}5^{a} \\
5^{a} \\
5^{a} \\
5^{a}\end{array}$ & $\begin{array}{l}1 \\
7 \\
2 \\
9\end{array}$ & $\begin{array}{l}\text { Prod +oil } \\
\text { Prod +oil } \\
\text { Prog +oil } \\
\text { Prog +oil }\end{array}$ \\
\hline $\begin{array}{l}6 \\
6 \\
6 \\
6\end{array}$ & $\begin{array}{l}50 \\
50 \\
50 \\
40\end{array}$ & $\begin{array}{r}-2 \\
=2 \\
-2 \\
0\end{array}$ & $\begin{array}{l}6^{\mathrm{a}} \\
6^{\mathrm{a}} \\
6^{\mathrm{a}} \\
6^{\mathrm{a}}\end{array}$ & $\begin{array}{r}1 \\
6 \\
11 \\
6\end{array}$ & $\begin{array}{l}\text { Prog +oil } \\
\text { Prog } \\
\text { Prog } \\
\text { Prog }\end{array}$ \\
\hline $\begin{array}{l}6 \\
9 \\
9 \\
9\end{array}$ & $\begin{array}{l}40 \\
40 \\
40 \\
40\end{array}$ & $\begin{array}{l}0 \\
0 \\
0 \\
0\end{array}$ & $\begin{array}{l}6^{\mathrm{a}} \\
3.6 \\
3.6 \\
3.6\end{array}$ & $\begin{array}{r}6 \\
7 \\
7 \\
11\end{array}$ & $\begin{array}{l}\text { Prog } \\
\text { Prov } \\
\text { Prov } \\
\text { Prov }\end{array}$ \\
\hline $\begin{array}{l}9 \\
9 \\
9 \\
9\end{array}$ & $\begin{array}{l}40 \\
47 \\
47 \\
47\end{array}$ & $\begin{array}{l}0 \\
0 \\
\circ \\
0\end{array}$ & $\begin{array}{l}3.6 \\
8 \\
8 \\
8\end{array}$ & $\begin{array}{r}11 \\
7 \\
7 \\
7\end{array}$ & $\begin{array}{l}\text { Prov } \\
\text { Prog+oil } \\
\text { Prog +oil } \\
\text { Prog +oil +Oe }\end{array}$ \\
\hline $\begin{array}{r}9 \\
12 \\
9 \\
9\end{array}$ & $\begin{array}{l}47 \\
42 \\
40 \\
40\end{array}$ & $\begin{array}{r}0 \\
0 \\
+1 \\
+1\end{array}$ & $\begin{array}{l}8 \\
4 \\
5 \\
5\end{array}$ & $\begin{array}{l}7 \\
7 \\
7 \\
7\end{array}$ & $\begin{array}{l}\text { Prog +oil +Oe } \\
\text { Prog +Oe } \\
\text { Oe } \\
\text { Prog }\end{array}$ \\
\hline $\begin{array}{l}9 \\
10 \\
10 \\
10\end{array}$ & $\begin{array}{l}40 \\
50 \\
40 \\
40\end{array}$ & $\begin{array}{r}1 \\
0 \\
0 \\
0\end{array}$ & $\begin{array}{l}5 \\
9 \cdot 2 \\
4 \\
4\end{array}$ & $\begin{array}{l}7 \\
7 \\
1 \\
7\end{array}$ & $\begin{array}{l}\text { Prog +Oe } \\
\text { Prog +oil +Oe } \\
\text { Prog +oil } \\
\text { Prog +oil+Oe }\end{array}$ \\
\hline $\begin{array}{r}11 \\
11 \\
9 \\
8\end{array}$ & $\begin{array}{l}4^{\circ} \\
4^{\circ} \\
4^{\circ} \\
4^{\circ}\end{array}$ & $\begin{array}{r}0 \\
0 \\
0 \\
+12\end{array}$ & $\begin{array}{l}4 \\
4 \\
4 \\
8\end{array}$ & $\begin{array}{l}7 \\
7 \\
7 \\
1\end{array}$ & $\begin{array}{l}\text { Prog +oil +Oe } \\
\text { Prog +oil } \\
\text { Prog +oil } \\
\text { Prog +oil }\end{array}$ \\
\hline $\begin{array}{r}8 \\
8 \\
15 \\
12\end{array}$ & $\begin{array}{l}40 \\
41 \\
43 \\
80\end{array}$ & $\begin{array}{r}+12 \\
0 \\
0 \\
0\end{array}$ & $\begin{array}{l}8 \\
4 \\
3.5 \\
3.5\end{array}$ & $\begin{array}{l}\mathbf{1} \\
\mathbf{1} \\
\mathbf{1} \\
\mathbf{I}\end{array}$ & $\begin{array}{l}\text { Prog }+\mathrm{Oe}+\text { oil } \\
\text { Oe } \\
\text { Prog }+ \text { Oe } \\
\text { Prog }\end{array}$ \\
\hline $\begin{array}{r}10 \\
9 \\
9 \\
10\end{array}$ & $\begin{array}{l}45 \\
45 \\
45 \\
45\end{array}$ & $\begin{array}{l}\mathbf{0} \\
\mathbf{0} \\
\mathbf{0} \\
\mathbf{0}\end{array}$ & $\begin{array}{l}6.25 \\
6.25 \\
6.25 \\
6.25\end{array}$ & $\begin{array}{l}1 \\
5 \\
5 \\
5\end{array}$ & $\begin{array}{l}\text { Prog }+ \text { Oe } \\
\text { Prog } \\
\text { Prog+Prod } \\
\text { Prod+Oe }\end{array}$ \\
\hline $\begin{array}{l}10 \\
10 \\
10 \\
10\end{array}$ & $\begin{array}{l}45 \\
45 \\
45 \\
45\end{array}$ & $\begin{array}{r}0 \\
-7 \\
-\quad 3 \\
+\quad 1\end{array}$ & $\begin{array}{l}6.25 \\
6.5 \\
6.5 \\
6.5\end{array}$ & $\begin{array}{l}5 \\
5 \\
5 \\
5\end{array}$ & $\begin{array}{l}\text { Prod }+ \text { Oe } \\
\text { Prog } \\
\text { Prog } \\
\text { Prog }\end{array}$ \\
\hline $\begin{array}{l}10 \\
10 \\
10 \\
14\end{array}$ & $\begin{array}{l}45 \\
45 \\
45 \\
45\end{array}$ & $\begin{array}{l}+5 \\
+9 \\
+13 \\
+17\end{array}$ & $\begin{array}{l}6.5 \\
6.5 \\
6.5 \\
6.5\end{array}$ & $\begin{array}{l}5 \\
5 \\
5 \\
5\end{array}$ & $\begin{array}{l}\text { Prog } \\
\text { Prog } \\
\text { Prog } \\
\text { Prog }\end{array}$ \\
\hline $\begin{array}{l}10 \\
10 \\
10 \\
10 \\
10\end{array}$ & $\begin{array}{l}43 \\
43 \\
43 \\
43 \\
43\end{array}$ & $\begin{array}{l}\mathbf{0} \\
\mathbf{0} \\
\mathbf{0} \\
\mathbf{0} \\
\mathbf{0}\end{array}$ & $\begin{array}{l}5 \cdot 0 \\
5 \\
5 \\
5 \\
5\end{array}$ & $\begin{array}{l}8 \\
8 \\
8 \\
8 \\
8\end{array}$ & $\begin{array}{l}\text { Prog+Oe } \\
\text { Prog+Oe } \\
\text { Prog } \\
\text { Prog+oil } \\
\text { Prog }\end{array}$ \\
\hline 467 & & & & & \\
\hline
\end{tabular}


I

BY ORAL ADMINISTRATION OF HORMONES

\begin{tabular}{|c|c|c|c|c|c|}
\hline \multirow{2}{*}{$\begin{array}{c}\text { Age of foetuses } \\
\text { when }+9 \\
\text { killed } \\
\text { (days) }\end{array}$} & \multirow{2}{*}{$\begin{array}{l}\text { No. } \text { 우 with } \\
\text { foetuses or } \\
\text { implant sites }\end{array}$} & \multicolumn{2}{|c|}{ Left uterine horn } & \multicolumn{2}{|c|}{ Right uterine horn } \\
\hline & & Live foetuses & Implant sites & Live foetuses & Implant sites \\
\hline $\begin{array}{l}7 \\
7 \\
7 \\
7\end{array}$ & $\begin{array}{l}0 \\
0^{\mathbf{b}} \\
3 \\
0\end{array}$ & $\begin{array}{r}0 \\
0 \\
14 \\
0\end{array}$ & $\begin{array}{l}0 \\
0 \\
0 \\
0\end{array}$ & $\begin{array}{l}0 \\
0 \\
4 \\
0\end{array}$ & $\begin{array}{l}\mathbf{0} \\
0 \\
0 \\
0\end{array}$ \\
\hline $\begin{array}{r}14 \\
7 \\
14 \\
7\end{array}$ & $\begin{array}{l}2 \\
1 \\
5 \\
2\end{array}$ & $\begin{array}{l}2 \\
2 \\
7 \\
6\end{array}$ & $\begin{array}{l}\mathbf{1} \\
\mathbf{0} \\
\mathbf{8} \\
\mathbf{0}\end{array}$ & $\begin{array}{r}4 \\
5 \\
10 \\
12\end{array}$ & $\begin{array}{l}3 \\
0 \\
9 \\
0\end{array}$ \\
\hline $\begin{array}{r}18 \\
13 \\
8 \\
15\end{array}$ & $\begin{array}{l}2 \\
4 \\
4 \\
2\end{array}$ & $\begin{array}{l}0 \\
3 \\
3 \\
0\end{array}$ & $\begin{array}{l}7 \\
3 \\
\mathbf{0} \\
\mathbf{8}\end{array}$ & $\begin{array}{l}0 \\
4 \\
4 \\
0\end{array}$ & $\begin{array}{l}5 \\
5 \\
3 \\
6\end{array}$ \\
\hline $\begin{array}{r}15 \\
7 \\
11 \\
8\end{array}$ & $\begin{array}{l}2 \\
6 \\
3 \\
4\end{array}$ & $\begin{array}{l}\mathbf{0} \\
\mathbf{0} \\
\mathbf{0} \\
\mathbf{0}\end{array}$ & $\begin{array}{r}9 \\
90 \\
9 \\
5\end{array}$ & $\begin{array}{l}\mathbf{0} \\
\mathbf{0} \\
\mathbf{0} \\
\mathbf{0}\end{array}$ & $\begin{array}{r}9 \\
14 \\
3 \\
7\end{array}$ \\
\hline $\begin{array}{r}8 \\
8 \\
15 \\
15\end{array}$ & $\begin{array}{l}3 \\
4 \\
6 \\
5\end{array}$ & $\begin{array}{r}0 \\
6 \\
14 \\
0\end{array}$ & $\begin{array}{r}5 \\
4 \\
11 \\
16\end{array}$ & $\begin{array}{r}0 \\
9 \\
11 \\
0\end{array}$ & $\begin{array}{r}7 \\
7 \\
12 \\
24\end{array}$ \\
\hline $\begin{array}{r}8 \\
7 \\
11 \\
11\end{array}$ & $\begin{array}{l}7 \\
0 \\
0 \\
6\end{array}$ & $\begin{array}{r}13 \\
0 \\
0 \\
28\end{array}$ & $\begin{array}{l}0 \\
0 \\
0 \\
2\end{array}$ & $\begin{array}{r}17 \\
0 \\
0 \\
19\end{array}$ & $\begin{array}{l}7 \\
0 \\
0 \\
5\end{array}$ \\
\hline $\begin{array}{r}11 \\
7 \\
7 \\
7\end{array}$ & $\begin{array}{l}8 \\
3 \\
5 \\
6\end{array}$ & $\begin{array}{r}1 \\
10 \\
13 \\
14\end{array}$ & $\begin{array}{r}25 \\
0 \\
0 \\
0\end{array}$ & $\begin{array}{r}2 \\
11 \\
12 \\
7\end{array}$ & $\begin{array}{r}22 \\
0 \\
0 \\
0\end{array}$ \\
\hline $\begin{array}{c}7 \text { to } 20 \\
7 \\
\text { I5 to } 20 \\
7\end{array}$ & $\begin{array}{l}7 \\
5 \\
7 \\
0\end{array}$ & $\begin{array}{l}1 \\
8 \\
2 \\
0\end{array}$ & $\begin{array}{r}10 \\
0 \\
12 \\
0\end{array}$ & $\begin{array}{l}\text { o } \\
7 \\
3 \\
\text { o }\end{array}$ & $\begin{array}{l}9 \\
\text { o } \\
7 \\
0\end{array}$ \\
\hline $\begin{array}{l}7 \\
7 \\
7 \\
7\end{array}$ & $\begin{array}{l}0 \\
0 \\
5 \\
0\end{array}$ & $\begin{array}{l}0 \\
0 \\
6 \\
0\end{array}$ & $\begin{array}{l}0 \\
0 \\
0 \\
0\end{array}$ & $\begin{array}{r}0 \\
0 \\
17 \\
0\end{array}$ & $\begin{array}{l}\mathbf{0} \\
\mathbf{0} \\
\mathbf{0} \\
\mathbf{0}\end{array}$ \\
\hline $\begin{array}{l}9 \\
10 \\
10 \\
10\end{array}$ & $\begin{array}{l}2 \\
5 \\
5 \\
0\end{array}$ & $\begin{array}{l}5 \\
4 \\
7 \\
0\end{array}$ & $\begin{array}{l}0 \\
2 \\
0 \\
0\end{array}$ & $\begin{array}{r}4 \\
5 \\
10 \\
0\end{array}$ & $\begin{array}{l}0 \\
8 \\
0 \\
0\end{array}$ \\
\hline $\begin{array}{r}10 \\
7 \\
7 \\
10\end{array}$ & $\begin{array}{l}0 \\
\text { I } \\
\text { I } \\
\text { I }\end{array}$ & $\begin{array}{l}0 \\
0 \\
0 \\
1\end{array}$ & $\begin{array}{l}0 \\
0 \\
1 \\
0\end{array}$ & $\begin{array}{l}0 \\
0 \\
0 \\
0\end{array}$ & $\begin{array}{l}\mathbf{0} \\
\mathbf{1} \\
0 \\
\mathbf{0}\end{array}$ \\
\hline $\begin{array}{l}7 \\
8 \\
8 \\
8\end{array}$ & $\begin{array}{l}2 \\
3 \\
1 \\
0\end{array}$ & $\begin{array}{l}1 \\
0 \\
0 \\
0\end{array}$ & $\begin{array}{l}0 \\
5 \\
0 \\
0\end{array}$ & $\begin{array}{l}3 \\
0 \\
0 \\
0\end{array}$ & $\begin{array}{l}0 \\
4 \\
1 \\
0\end{array}$ \\
\hline \multirow[t]{2}{*}{$\begin{array}{l}\mathbf{8} \\
\mathbf{8} \\
\mathbf{8} \\
\mathbf{9} \\
7\end{array}$} & $\begin{array}{l}4 \\
5 \\
5 \\
4 \\
4\end{array}$ & $\begin{array}{r}2 \\
1 \\
10 \\
5 \\
3\end{array}$ & $\begin{array}{l}0 \\
6 \\
2 \\
0 \\
1\end{array}$ & $\begin{array}{l}0 \\
3 \\
5 \\
6 \\
3\end{array}$ & $\begin{array}{l}5 \\
2 \\
0 \\
3 \\
4\end{array}$ \\
\hline & 160 & 192 & 162 & 197 & 192 \\
\hline
\end{tabular}


Ova were examined under $36 \times$ magnification after recovering them by flushing the horns of the uterus with a small quantity of $0.9 \%$ sodium-chloride solution 86 to I08 hr after insemination. For the purposes of this report, only those ova that were in the blastocyst stage were included in the data. Because of the variability in stage of development, ova in the morula stage, fragmenting ova and cytolyzed ova were arbitrarily classified separately.

The mice were treated in fifty-three groups consisting of four to thirty females per group. Animals were assigned to experimental subgroups in a fashion that would permit testing for a series of varied factors associated with artificial insemination. The effects of each factor were evaluated by relating the treatment to the percentage of ova recovered that were blastocysts.

All animals in which induced ovulation was attempted were inseminated. Animals were not selected on the basis of vaginal smears or the presence of copulation plugs as has been the case in most prior work with artificial insemination of mice. Data from fifty-six inseminated animals from all groups were excluded from analysis because no ova, either fertilized or not, were recovered from them, indicating failure to induce ovulation. Data from fortynine other animals were also excluded because they comprised whole groups in which no blastocysts were found in any member of the group, indicating: (a) a defect in the insemination technique, shared by all members of the group, $(b)$ a defect in the fertilizing capacity of the spermatozoa or $(c)$ inability of the ova to become blastocysts.

PART 2

Fifty-three groups of prepuberal females 30 to $5^{0}$ days of age of either a hybrid strain (BALB/cGnRr $\times \mathrm{A} / \mathrm{Jax}$ ) (I 50 animals) or random-bred albinos (317 animals) were the experimental females (Table I). Ovulation was induced as in Part I. Spermatozoa were furnished by random-bred albino males. Spermatozoa from one male were used to inseminate five or six females. The average number of spermatozoa per insemination in this trial was $5 \times 10^{6}$, with a range of 3.6 to $9.2 \times 10^{6}$. The insemination procedure was essentially the same as in Part 1 , except that most mice were inseminated near the time of ovulation with spermatozoa stored for 2 to $3 \mathrm{hr}$.

Inseminated females were fed a treated diet containing crystalline progesterone or progestationally-active compounds, or these materials in combination with various oestrogens. Among the many levels (milligrammes of hormone per gramme dry diet) and combinations of hormones fed, the most commonly used were as follows : $4,6,8$, or to $\mathrm{mg}$ progesterone; $2.5 \mathrm{mg}$ Prodox *; $0.2 \mathrm{mg}$ Provera $\uparrow$; $0.002 \mathrm{mg}$ oestradiol with $8 \mathrm{mg}$ progesterone; $0.0008 \mathrm{mg}$ oestradiol with $8 \mathrm{mg}$ progesterone; $0.0008 \mathrm{mg}$ oestradiol with $6 \mathrm{mg}$ Prodox; $0.0002 \mathrm{mg}$ diethylstilboestrol with ro $\mathrm{mg}$ progesterone.

Treated diets were prepared by grinding a commercial, pelleted mousediet (Rockland), dissolving the hormone in corn oil, or $95 \%$ ethyl alcohol, and thoroughly mixing these ingredients. The addition of one part by weight of water or reconstituted dry-skim milk to two parts of diet made it possible to

* I 7 -hydroxyprogesterone acetate, Upjohn Co.

$\dagger 6 \propto$-methyl-I 7-hydroxyprogesterone acetate, Upjohn Co. 
repellet or reform the diet. The reformed diet was then dried in an oven at about $65^{\circ} \mathrm{C}$ for 18 to $28 \mathrm{hr}$. Hormone intake was determined in many groups by weighing the feed and feeders daily and subtracting the amount of wasted feed recovered under the cage. The mice were usually not fed the diet containing hormone until 7 to Io days after insemination so that any mice spontaneously implanting due to stimulation of the vagina and cervix (about $\mathrm{I} \%$ of inseminated females) could be more easily detected at autopsy by the presence of large foetuses. The diets containing the hormone were then fed Io to 18 days and the mice were autopsied. Implantation sites and foetuses were counted and their condition and the condition of the uterus and ovaries were noted.

\section{RESULTS AND DISCUSSION}

PART I

A statistical analysis (fitted constants) of the data was made with the aid of an electronic computer. The angularly-transformed percentage of blastocysts was the dependent variable and there were seventeen independent variables as indicated in the methods section.

No statistically significant difference was revealed due to the following variables within the ranges studied: ( 1 ) both the interval between collection of spermatozoa to insemination and the square of this interval, (2) number of females inseminated per male donor, (3) volume of sperm suspension introduced into each female, (4) interval between insemination and examination for blastocysts, (5) interval between injection of PMS and injection of HCG, (6) interaction of the interval of time between collection of spermatozoa to insemination with the origin of the spermatozoa, that is, from either the vas deferens or epididymis or both, (7) interaction of the in-vitro storage period of the spermatozoa with the interval from ovulation to insemination, (8) interaction of the source of the spermatozoa with time interval from ovulation to insemination. There appeared to be an important effect of motility, the percentage of blastocysts increasing as the motility score of the sperm suspension increased. The relationship between sperm motility and fertilizing capacity has been noted in most species. Because in all species spermatozoa do have a finite in-vitro life at above-freezing storage temperatures, the fact that in these experiments no differences were noted due to length of storage period indicates that sufficient spermatozoa were able to survive at least $24 \mathrm{hr}$ to achieve a normal fertilization rate. Further tests with longer storage periods and constant sperm numbers need to be conducted to determine how long mouse spermatozoa can be stored and still retain fertilizing capacity.

Blastocysts were recovered from four of seven females inseminated with spermatozoa which were removed from a male $24 \mathrm{hr}$ after he was killed and the intact mouse was cooled to $7^{\circ} \mathrm{C}$. This information is insufficient to permit comparison of the effectiveness of in-vitro with in-situ storage of spermatozoa at lowered temperatures but does substantiate the finding that cooled mouse spermatozoa retain fertilizing capacity for at least $24 \mathrm{hr}$ whether in or out of the male reproductive tract. 
The number of females inseminated per male donor is an indirect indication of the number of spermatozoa each female received. Apparently, there was an excess even in those cases in which spermatozoa from one male were divided among eight females. Additional dilutions and sperm counts of inseminated sperm suspensions are necessary to determine the minimum number of spermatozoa required for successful insemination in mice. The observation in these experiments that the source of the spermatozoa had no significant effect indicates that spermatozoa in the epididymis are able to fertilize ova of any age equally as well as spermatozoa in the vas deferens. Because the epididymis contains many more spermatozoa than the vas deferens, more females can be inseminated by spermatozoa from one male than if the vas deferens is the sole source. In some cases, the vas deferens is almost empty of spermatozoa which is further reason to try to use those from the epididymis.

\section{TABLE 2}

EFFECT OF INSEMINATION-TO-OVULATION INTERVAL ON NUMBER OF BLASTOCYSTS FORMED

\begin{tabular}{l|rrr|r}
\hline Insemination-to-ovulation interval $(\mathrm{hr})$ & -2 & 10 & 13 & Total \\
\hline No. females inseminated & 169 & 26 & 29 & 224 \\
No. females containing blastocysts & 107 & 21 & 26 & 154 \\
Percentage of females containing blastocysts & 63 & $8 \mathrm{I}$ & 90 & 69 \\
Total No. ova and blastocysts recovered & 163 & 126 & 224 & $15 \mathrm{I} 3$ \\
No. blastocysts recovered & 429 & 90 & 146 & 665 \\
Percentage of total ova that were blastocysts & 37 & $7 \mathrm{I}$ & 65 & 44 \\
\hline
\end{tabular}

Table 2 shows the effect of varying the insemination-to-ovulation interval on both the conception rate among females and on the rate of fertility among ova. Both criteria for evaluating the degree of success of artificial insemination (rate of conception among females and rate of fertility among ova) indicate that artificial insemination was quite effective when performed 10 or $13 \mathrm{hr}$ after ovulation. This demonstrates a longer fertilizable life of the mouse ovum than had been previously indicated (Runner \& Palm, I953). The high proportion of recovered ova that were blastocysts reduces the possibility that these blastocysts resulted from recently ovulated ova since Runner \& Palm (1953) and Gates \& Beatty (1954) have shown that ovulation is nearly complete by I6 hr after HCG. At the time of insemination, the vaginas of those animals inseminated Io or $13 \mathrm{hr}$ after ovulation contained large amounts of cellular debris, characteristic of the contents of the vagina of a mouse in metoestrus. This is further indication that they were in a postoestrous condition. There was an effect of the time interval between ovulation and insemination. The effect is curvilinear, the quadratic coefficient being significant. The maximum percentage of ova that were blastocysts occurs after inseminating at about $6 \mathrm{hr}$ after ovulation. This is contrary to the concept that spermatozoa should be at the fertilization site at the time of ovulation so that sperm penetration may begin without delay. These trials do not suggest any reason for the apparent advantage in inseminating after ovulation has occurred, unless the ova resulting from induced ovulation of prepuberal mice are peculiar in this respect. Further 
experiments are required to test whether normal proportions of ova that have been fertilized at least io to $13 \mathrm{hr}$ after ovulation can survive to term.

PART 2

Four hundred and sixty-seven females comprising fifty-three groups of about eight to ten mice each were inseminated and later fed a treated diet (Table I). Forty-one groups comprised of 374 mice had implantation sites or foetuses in at least one member of the group. Forty-three per cent of the animals in these groups ( 160 animals) contained either foetuses or implantation sites in spite of the inconstancies associated with induced ovulation, artificial insemination, delayed implantation, artificial induction of implantation and oral administration of hormones. There was an average of 4.6 foetuses or implantation sites per pregnant female. Of the 743 implantation sites or foetuses found at autopsy, $389(52 \%)$ were considered to be normal foetuses. Failure to maintain viability of all foetuses may possibly be attributed to many causes: too low a hormone level in the diet, low feed-intake on one or more days, improper balance of progesterone and oestrogen in the treated diet, the intrinsic level of hormones in the mouse as influenced by age, strain, etc. Neither implant nor foetus was found in any of the groups treated as follows: fed a diet containing only oestrogens; fed normal, control diet; smaller or younger animals fed Prodox or Provera.

The observation that foetuses were found at autopsy 7 or I4 days after initiation of treatment in animals inseminated $12 \mathrm{hr}$ after ovulation indicates that unfertilized ova aged for $\mathrm{I} 2 \mathrm{hr}$ prior to fertilization are capable of developing to at least I2-day foetuses. There are insufficient numbers to determine the comparative efficiency of development of these aged ova. Spontaneous implantation, characterized by the presence of functional corpora lutea and foetuses of more advanced age, occurred in about $\mathrm{I} \%$ of the cases. These animals were omitted from the data.

In one case, a group of animals inseminated at the same time was divided into three subgroups. The treatment was then begun in one subgroup the Ist day after insemination, on the 6th day in Subgroup 2 and on the II th day after insemination in Subgroup 3. At autopsy 18 days after insemination, foetuses of three different sizes were recovered from the different groups. An adequate comparison of survival rates after the different periods of delay is not possible due to limited data.

The addition of oestrogen to the progesterone-containing diets enhanced the implantation rate in some cases and the uteri appeared more vascular, especially in younger and smaller mice. The older, larger mice did not seem to require any exogenous oestrogen whereas the smaller, younger mice seemed to require oestrogen for optimum implantation. Comparison of observations in older mice, which implanted quite well with progesterone alone, with observations on similar mice receiving both oestrogen and progesterone indicated that oestrogen addition in those cases was actually detrimental to foetal survival but not necessarily detrimental to implantation rate. In most cases, progesterone alone was sufficient to maintain implantation in an apparently reasonably normal fashion. Calculations based on feed-intake data ( 2 to $5 \mathrm{~g}$ 
diet/mouse/day) indicated that the mice may have ingested from 8 to $50 \mathrm{mg}$ of progesterone per mouse per day. There is no indication on the basis of the limited comparative data that the higher levels of progesterone increased either the percentage of females that contained foetuses and implantation sites or the number of implantations in each female.

Literature reports of attempts to maintain pregnancy in ovariectomized animals usually indicate that oestrogen and progesterone are both essential. Because progesterone alone was effective in permitting implantation and foetal development in some cases, it is possible to speculate that progesterone is either absent or is a limiting factor in those mice, and oestrogen is present in approximately sufficient amounts. On the other hand, in the very young mouse, which seemed to benefit by exogenous oestrogen, both oestrogen and progesterone were apparently deficient. These observations point out the complexity of relationships between sexual maturity of the mouse, age of the mouse and the kinds, amounts and proportions of exogenous hormones required for implantation and foetal development. Oestrogen alone never caused implantation as it does in lactating rats with delayed implantation.

The addition of corn oil to the diet before reforming seems to enhance the effect of the hormones added. Umberger \& Gass (1958) also noted an effect of the level of fat in the diet on the response of orally administered diethystilboestrol. It is unknown whether a high-fat diet stimulates food consumption or has a metabolic influence or whether it may have a physical influence on the rate of absorption and deposition of the steroid hormones.

In one case, an animal that appeared to be in an advanced stage of pregnancy I 8 days after artificial insemination was allowed to litter and produced thirteen normal young at 66 days of age. It had been fed progesterone from the 7 th through the 18 th day after insemination. There was no delay in implantation as indicated both by the size of the foetuses and the interval between insemination and parturition. Progesterone in addition to that required to permit implantation and foetal development was apparently not harmful to this mouse.

Attempts to induce parturition in females not spontaneously implanting but fed a diet containing progesterone by withdrawing the treated diet resulted in failure. In these cases, the diet containing progesterone was fed for 18 days after which the normal diet was fed. The interval between insemination and initiation of the treatment was delayed until 7 days after insemination so that the animals had foetuses comparable to normal I8-day-old foetuses on the $25^{\text {th }}$ day after insemination. The birth canal was not enlarged in any of those cases. There were no apparent defects in the foetuses and it appeared at autopsy that they had grown to normal size but had died during attempted parturition.

\section{ACKNOWLEDGMENTS}

Part I of this study was carried out in 1957 while the senior author was a visiting investigator at the Roscoe B. Jackson Memorial Laboratory, Bar Harbor, Maine.

This investigation was supported in part by a Research Grant (5300) from 
the National Institutes of Health, Public Health Service, awarded to Roscoe B. Jackson Memorial Laboratory.

The authors express their appreciation for the assistance given by Allen Gates, Cora Harris and Eileen McKibben Gabrielson (R. B. Jackson Laboratory) in carrying out this study and to H. W. Norton, Station Statistician (University of Illinois), for the statistical analyses.

\section{REFERENCES}

BLANDAu, R. J. \& JoRdAn, E. S. (1941) The effect of delayed fertilization on the development of the rat ovum. Amer. F. Anat. 68, 275.

BLANDAU, R. J. (1952) Effects of delayed fertilization on the development of the pronuclei in rat ova. Fertility \& Sterility, 3, 349.

Braden, A. W. H. \& Austin, C. R. (1954a) The fertile life of mouse and rat eggs. Science, 120, 610 .

BrADEN, A. W. H. \& Austin, C. R. (1954b) Fertilization of the mouse egg and the effect of delayed coitus and of hot-shock treatment. Aust. F. biol. Sci. 7, 522.

EDWARDs, R. G. (1955) Selective fertilization following the use of sperm mixtures in the mouse. Nature, Lond. $175,215$.

Gates, A. H. \& Beatty, R. A. (1954) Independence of delayed fertilization and spontaneous triploidy in mouse embryos. Nature, Lond. $\mathbf{r 4 4}, 356$.

KILE, J. C., JR. (195I) An improved method for artificial insemination of mice. Anat. Rec. 1o9, 1og.

Melrose, D. R. (1956) Skim milk powder as a semen diluent. Proc. IIIrd int. Congr. Anim. Reprod., Cambridge, Section 3, p. 68.

RunNer, M. (1947) Attempts at in vitro semination of mouse egg. Anat. Rec. 99, 564.

RunNer, M. N. \& Gates, A. (I954) Conception in prepuberal mice following artificially induced ovulation and mating. Nature, Lond. 174, 222.

Runner, M. N. \& PaLM, J. (1953) Transplantation and survival of unfertilized ova of the mouse in relation to postovulatory age. F. exp. Zool. 124, 303 .

SmithBerg, M. \& RunNer, M. N. (1956) The induction and maintenance of pregnancy in prepuberal mice. F. exp. Zool. 133, 44I.

SMITHBERG, M. (1958) Attempts to induce and maintain pregnancy in prepuberal mice following treatment with i 7 -hydroxyprogesterone i 7 -n-caproate. Ann. N.Y. Acad. Sci. 7I, 555 .

SNell, G. D., Hummel, K. P. \& AbelmanN, W. H. (1943) A technique of artificial insemination of mice. Anat. Rec. 87, 473 .

Sneld, G. D., Hummel, K. P. \& Abelmann, W. H. (1944) A technique for the artificial insemination of mice. Anat. Rec. 9o, 243.

UMBerger, E. J. \& GAss, G. H. (1958) The effect of dietary fat on the uterine-weight response of immature mice to oral stilbestrol. Endocrinology, 63, 80 r. 